The Best American History

Essays 2006 



\title{
The Best American History Essays 2006
}

\author{
Edited by \\ Joyce Appleby for the \\ Organization of American Historians
}




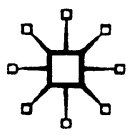

THE BEST AMERICAN HISTORY ESSAYS 2006

(C) Edited by Joyce Appleby for the Organization of American Historians, 2006.

Softcover reprint of the hardcover 1st edition 2006 978-1-4039-6840-1

All rights reserved. No part of this book may be used or reproduced in any manner whatsoever without written permission except in the case of brief quotations embodied in critical articles or reviews.

First published in 2006 by

PALGRAVE MACMILLANTM

175 Fifth Avenue, New York, N.Y. 10010 and

Houndmills, Basingstoke, Hampshire, England RG21 6XS

Companies and representatives throughout the world.

PALGRAVE MACMILLAN is the global academic imprint of the Palgrave Macmillan division of St. Martin's Press, LLC and of Palgrave Macmillan Ltd.

Macmillan ${ }^{\circledR}$ is a registered trademark in the United States, United Kingdom

and other countries. Palgrave is a registered trademark in the European

Union and other countries.

ISBN 978-1-4039-6852-4 ISBN 978-1-137-06580-3 (eBook)

DOI 10.1007/978-1-137-06580-3

Library of Congress Cataloging-in-Publication Data

The best American history essays of 2006 / edited by Joyce Appleby for the Organization of American Historians.

p. cm.

Includes bibliographical references and index.

ISBN 978-1-4039-6840-1 (alk. paper)

1. United States-History. 2. American essays. 3. United States-

Historiography. I. Organization of American Historians.

E178.6.015 2006

973-dc22

A catalogue record for this book is available from the British Library.

Design by Newgen Imaging Systems (P) Ltd., Chennai, India.

First edition: April 2006

109876654321

Transferred To Digital Printing 2011 


\section{Contents}

List of Illustrations vii

Introduction $\quad 1$

Joyce Appleby

$\begin{array}{lll}\text { Chapter } 1 \text { Inventing the Presidency } & 11\end{array}$

Joseph Ellis

From American Heritage

Chapter 2 "Divide et Impera": Federalist 10 in a

Wider Sphere

Woody Holton

From The William and Mary Quarterly

Chapter 3 “Overrun with Free Negroes": Emancipation

and Wartime Migration in the Upper Midwest

Leslie A. Schwalm

From Civil War History

Chapter 4 The Work Ethic of the Plain Folk: Labor

and Religion in the Old South

Carl R. Osthaus

From The Journal of Southern History

Chapter 5 “' 'It Was Like All of Us Had Been Raped':

Sexual Violence, Community Mobilization, and

the African American Freedom Struggle"

Danielle L. McGuire

From The Journal of American History

Chapter 6 Popular Culture in the Age of White

Flight: Film Noir, Disneyland, and the

Cold War (Sub)Urban Imaginary

Eric Avila

From The Journal of Urban History

Chapter 7 Sing Sheng vs. Southwood:

Residential Integration in Cold War California

Charlotte Brooks

From The Pacific Historical Review 
vi Contents

Chapter 8 Murder and Biblical Memory: The Legend of Vernon Johns

Ralph E. Luker

From The Virginia Magazine of History and Biography

Chapter 9 Affirmative Action from Below: Civil Rights, the Building Trades, and the Politics of Racial Equality in the Urban North, 1945-1969

Thomas J. Sugrue

From The Journal of American History

Chapter 10 The Suburban Origins of "Color-Blind"

Conservatism: Middle-Class Consciousness

in the Charlotte Busing Crisis

Matthew D. Lassiter

From The Journal of Urban History

Other Articles Nominated for the 2006 Competition 


\section{List of Illustrations}

1.1 L'Enfant-McMillan Plan of Washington, DC

2.1 Herman Husband compares a state to a human hand.

A Dialogue between an Assembly-Man and a Convention-Man, on the Subject of the State

Constitution of Pennsylvania ... (Philadelphia, 1790)

2.2 Herman Husband, A Dialogue between an Assembly-Man and a Convention-Man, on the Subject of the State Constitution of Pennsylvania ... (Philadelphia, 1790), between pages 8 and 9 . Herman Husband used a map of North America and a diagram of a human body to demonstrate his belief that the various layers of representative government in the United States should exhibit the same proportionality as the human body

6.1 Visiting Model Homes in Lakewood, ca. 1951

8.1 Vernon Johns, ca. 1959

10.1 Charlotte Map 1970: Distribution of the Black Population of the City of Charlotte and Mecklenburg Country, 1970, by Census Tract

10.2 Charlotte Map 2000: Distribution of the Black Population of the City of Charlotte and Mecklenburg Country, 2000, by Census Tract 